\title{
Pengaruh zonasi dalam kandang closed house terhadap kadar amonia dan dampaknya pada kualitas daging broiler di musim penghujan
}

\section{The effect of zonation in closed house on ammonia levels and its impact to broiler meat quality in rainy season}

\author{
Renata, T.A. Sarjana *, dan S. Kismiati \\ Departemen Peternakan, Fakultas Peternakan dan Pertanian \\ Universitas Diponegoro, Semarang, 50275
}

Submitted: 30 Juli 2018, Accepted: 29 Agustus 2018

\begin{abstract}
ABSTRAK: Penelitian bertujuan untuk mengetahui pengaruh zonasi dalam kandang terhadap kadar amonia dan dampaknya pada kualitas daging broiler di musim penghujan. Penelitian dilaksanakan di kandang closed house, Fakultas Peternakan dan Pertanian, Universitas Diponegoro. Tiga ratus enam puluh ayam pedaging dibagi menjadi 24 kelompok (4 pelakuan, 6 kelompok penempatan broiler): T1 (Zona 1; pada posisi inlet kandang), T2 (Zona 2; 1/4 dari panjang kandang), T3 (Zona 3; 1/2 dari panjang kandang); T4 (Zona 4; 3/4 dari panjang kandang). Selama penelitian kadar amonia, suhu, kelembaban, dan kecepatan angin di dalam dan luar kandang diambil sebagai data yang mendukung pengaruh zonasi pada kadar amonia dalam kandang dan untuk memperoleh gambaran beberapa faktor yang memiliki kontribusi terhadap kadar amonia. Parameter yang diamati adalah daya ikat air, $\mathrm{pH}$, warna, kadar air, kadar lemak, dan kadar protein. Hasil penelitian menunjukkan bahwa warna daging paha atas mengalami peningkatan secara signifikan pada zona dekat outlet $(\mathrm{p}<0,05)$, namun daya ikat air dan warna daging paha bawah dan dada tidak mengalami peningkatan $(\mathrm{p}>0,05)$ pada zona dekat outlet, tetapi memiliki warna daging yang semakin gelap pada zona dekat outlet. $\mathrm{pH}$ tidak menunjukkan perbedaan nyata $(\mathrm{p}>0,05)$ pada zona dekat outlet. Kadar air diikuti kadar lemak daging dada tidak menunjukkan perbedaan nyata $(\mathrm{p}>0,05)$ akibat zonasi. Kadar protein daging dada secara signifikan naik $(\mathrm{p}<0,05)$ pada zona dekat outlet. Kesimpulan dari penelitian ini adalah penempatan pada zona mendekati outlet berdampak terhadap peningkatan daya ikat air, warna, dan protein kasar daging. Meskipun demikian peningkatan pada protein daging pada zona dekat outlet tidak diikuti dengan massa protein daging yang meningkat.
\end{abstract}

Kata kunci : kualitas daging broiler; ammonia; zonasi; musim penghujan.

\begin{abstract}
This experiment was conducted to determine the effect of zonation in closed house on ammonia levels and its impact on broiler chicken quality in the rainy season. The research was held in closed house, Faculty of Animal Husbandry and Agriculture, Diponegoro University. Three hundred and sixty broilers were divided into 24 groups ( 4 treatment, 6 placement groups of broiler): T1 (Zone 1, at the inlet position of the cage), T2 (Zone 2; 1/4 of the length of the cage), T3 (Zone 3; 1/2 from the length of the cage ); T4 (Zone $4 ; 3 / 4$ of the length of the cage). During the study of ammonia levels, the temperature, humidity, and wind velocity inside and outside the cage were taken to obtain an overview of several factors that contribute to ammonia levels. The parameters observed were water holding capacity, $\mathrm{pH}$, color, moisture content, fat content, and protein content. Water holding capacity and the color of the upper thigh meat increased significantly in the zone near the outlet $(\mathrm{p}<0.05)$, but the water holding capacity and the color of the lower thighs and breast meat did not increase $(p>0.05)$ in the zone near the outlet, but it has a darker meat color on the zone near the outlet. The $\mathrm{pH}$ did not show any significant difference ( $\mathrm{p}>0.05)$ in the zone near the outlet. Water content followed by fat content of breast meat showed no significant difference ( $p>0.05)$ due to zoning. Breast protein content significantly increased $(p<0.05)$ in the zone near the outlet. It was concluded that placement in the zone near outlet had impact on the increase of water holding capacity, color, and protein content. Nevertheless, an increase in meat protein in the zone near the outlet is not followed by increased meat protein mass.
\end{abstract}

Keywords: quality of broiler meat; ammonia; zonation; rainy season.

*Corresponding Author: teysar_adi@undip.ac.id 


\section{PENDAHULUAN}

Broiler merupakan ayam yang memiliki produktifitas tinggi sebagai penghasil daging. Broiler merupakan ternak ayam yang mengalami pertumbuhan paling cepat dibandingkan ternak ayam yang lain, dikarenakan hasil budidaya dari teknologi maju (Pratikno, 2010). Kelemahan dari pemeliharaan ayam broiler adalah adaptasi lingkungan yang sulit dan risiko kematian yang tinggi. Indonesia sendiri merupakan negara dengan iklim tropis yang memiliki suhu tinggi dan kelembaban rendah. Broiler berproduksi maksimal pada suhu $18^{\circ} \mathrm{C}$ $22^{\circ} \mathrm{C}$ (Charles, 2002). Suhu lingkungan pada iklim tropis di Indonesia menurut data BMKG (Badan Meteorologi Klimatologi dan Geofisika) berada pada rata - rata $28^{\circ} \mathrm{C}$ $-32^{\circ} \mathrm{C}$. Suhu lingkungan yang terlalu tinggi dan diikuti kelembaban yang tinggi memyebabkan turunnya produksi. Hal tersebut membuat dibutuhkannya kandang closed house untuk mensiasati hal tersebut.

Closed house adalah kandang tertutup yang dilengkapi dengan tempat pakan, tempat minum, alat penerangan, sistem pemanas/ brooder, exhaust fan, cooling pad, sensor, panel listrik, dan tirai. Penggunaan kandang closed house pada pemeliharaan ayam broiler untuk mengurangi pengaruh dari suhu di luar kandang (Sujana, Darana, dan Setiawan, 2011). Memelihara broiler dalam jumlah banyak dalam satu kandangakan menghasilkan amonia yang cukup tinggi. Amonia adalah fermentasi asam urat dalam ekskreta. Amonia terbentuk dari votilisasi ammonia, kondisi yang mendukung terjadinya votilisasi amonia adalah suhu hangat, kelembabab, dan $\mathrm{pH}$ yang normal namun cenderung sedikit tinggi (Sarjana dkk. 2017). Gas amonia yang dihasilkan dalam kandang berasal dari hasil fermentasi antara ekskreta dan litter kandang yang mengalami dekomposisi menjadi urea (Pereira, 2017). Kadar amonia yang tinggi mempengaruhi perfoma ayam, meningkatkan kerentanan penyakit dan mortalitas tinggi (Miles, Branton, dan Lott, 2004). Kadar amonia yang tinggi pada kandang ayam broiler dapat mempengaruhi performa ayam broiler. Performa ayam yang turun dapat mempengaruhi kualitas daging ayam broiler (Assad, Widiastuti, dan Sugiharto, 2016). Closed house mempunyai zonasi di dalamnya, dimana pada zona 1 dekat dengan cooling pad memiliki suhu yang lebih rendah dibandingkan dengan zona 4 yang dekat dengan exhaust fan, yang mendapatkan akumulasi panas dari zona 1 sampai zona 4 . Hal ini menyebabkan perbedaan suhu, kelembaban, dan kadar amonia pada closed house.

Musim penghujan juga mempengaruhi kadar amonia di kandang closed house, dikarenakan kelembaban yang tinggi mengakibatkan amonia dalam kandang menguap lebih cepat di udara sehingga kadar amonia di udara lebih besar (William dan Meijerhof, 1990). Kelembaban yang tinggi dalam kandang juga menyebabkan sulitnya ayam untuk melepas panas dalam tubuh apalagi pada periode finisher karena ukuran tubuh yang lebih besar, sehingga panas di dalam tubuh terakumulasi dengan kadar amonia yang tinggi dalam kandang, berakibat pada stres oksidatif pada ayam dan mempengaruhi kualitas daging. Produksi amonia yang ada di dalam kandang dapat mempengaruhi kualitas daging ayam broiler. Produksi amonia yang berkepanjangan pada kandang ayam broiler tertutup mengakibatkan stress oksidatif dimana aktivitas radikal bebas melebihi antioksidan dan mempengaruhi kualitas daging (Xing dkk., 2016).

Penelitian ini bertujuan untuk mengetahui pengaruh zonasi pada kandang closed house terhadap produksi amonia dan dampaknya pada kualitas daging broiler di musim penghujan. Manfaat dari penelitian adalah memberikan informasi pengaruh zonasi dalam kandang dan dampaknya pada produksi amonia dan kualitas daging broiler. 


\section{MATERI DAN METODE}

Materi yang digunakan dalam penelitian ini meliputi broiler sebanyak 360 ekor DOC unsex yang dipelihara selama 28 hari dengan rata - rata bobot badan awal $44,80 \pm 1,66$ g. Peralatan yang digunakan antara lain ammonia detector untuk mengukur kadar amonia, thermohygrometer untuk mengukur suhu dan kelembaban, timbangan gantung untuk mengukur bobot badan ayam,timbangan analitik untuk menimbang karkas dan daging, jaring untuk membagi zona antar kandang, pisau dan gunting untuk prosessing.

Tahapan penelitian meliputi tiga tahap yaitu tahap persiapan, tahap pelaksanaan dan tahap pengolahan data. Tahap persiapan penelitian meliputi persiapan kandang dan peralatan yang akan digunakan. Ayam yang digunakan diambil dari kandang closed house Fakultas Peternakan dan Pertanian, Universitas Diponegoro, Semarang. Persiapan selanjutnya adalah persiapan kandang untuk pengamatan, pengadaan amoniameter untuk mengukur kadar amonia dalam kandang, thermohygrometer untuk mengukur suhu dan kelembaban dalam dan luar kandang. Kondisi Makromikroklimat kandang selama penelitian dapat dilihat pada Tabel 1. Nilai heat stress index juga dihitung sebagai data pendukung untuk mengetahui tingkat stress pada broiler. Heat stress index dihitung dengan menjumlahkan suhu dalam satuan Farenheit dan kelembaban udara dalam persen.

Rancangan percobaan yang digunakan adalah rancangan acak kelompok (RAK). Pengelompokan berdasarkan zonasi dalam kandang closed house, yang terdiri dari 4 perlakuan dan 6 kelompok penempatan broiler, terdapat 24 unit percobaan. Parameter yang diamati dalam penelitian ini adalah kualitas daging yaitu Water Holding Capacity (WHC), pH daging, warna daging, kadar air, kadar lemak kasar, dan kadar protein kasar diukur melalui prosedur analisis proksimat. Data yang diperoleh dianalisis ragam dengan menggunakan Rancangan Acak Kelompok (RAK) dengan program SAS 9.1 (Statistical Analysis System). Jika terdapat perbedaan yang signifikan antar perlakuan dilanjutkan dengan Uji Duncan dengan taraf 5\%.

Metode pengujian WHC pada daging ayam dilakukan dengan prosedur yang dijelaskan oleh Barbut (1993), nilai $\mathrm{pH}$ diukur dengan $\mathrm{pH}$ meter sesuai prosedur oleh Soeparno (2005), pengujian warna daging dilakukan pengambilan gambar daging, bagian paha atas, paha bawah, dan dada, kemudian hasil digital imaging dianalisis. Tingkatan gelap warna daging ditentukan berdasarkan nilai RGB digital imaging yang diambil dan diamati dengan program Photoshop CS6 Portable. Hasil nilai digital imaging menunjukkan hasil warna daging, semakin tinggi nilai RGB warna daging semakin terang. Pengujian kadar air dilakukan dengan prosedur yang dijelaskan oleh Sudarmadji, Haryono, dan Suhardi (1989), pengujian kadar lemak dilakukan sesuai metode yang dijelaskan oleh Apriyantono dkk. (1987), pengujian kadar protein dilakukan sesuai metode yang dijelaskan oleh AOAC (1984). Pada penelitian ini data massa protein daging dada juga dihitung sebagai data pendukung, untuk memperoleh gambaran tingkat deposisi protein, berdasarkan standar kalkulasi daging dan tulang dari penelitian Hayse dan Marion (1973) dengan nilai 2,43 . 
Tabel 1. Rata-rata kondisi makro-mikroklimat kandang selama penelitian

\begin{tabular}{lcccc}
\hline \multirow{2}{*}{ Makroklimat } & \multicolumn{4}{c}{ Minggu ke- } \\
\cline { 2 - 5 } & I & II & III & IV \\
\hline Suhu $\left({ }^{0} \mathrm{C}\right)$ & 26,23 & 25,38 & 25,76 & 25,20 \\
Rh $(\%)$ & 83,24 & 89,47 & 89,85 & 91,88 \\
CurahHujan & 131,20 & 109,60 & 111,80 & 147,60 \\
Mingguan $(\mathrm{mm})$ & & & & \\
Radiasi $\left(\mathrm{W} / \mathrm{m}^{2}\right)$ & 182,50 & 163,02 & 105,47 & 109,13 \\
& & & & \\
\hline Mikroklimat & & & & \\
\hline Suhu $\left({ }^{0} \mathrm{C}\right)$ & 31,97 & 28,48 & 28,00 & 92,16 \\
Rh $(\%)$ & 78,92 & 86,80 & 91,24 & 0,98 \\
Kecepatan Angin & 0,02 & 0,21 & 1,19 & \\
$(\mathrm{~m} / \mathrm{s})$ & & & & \\
\hline
\end{tabular}

Ket : Makroklimat berdasarkan data Automatic Weather Stasion FPP, UNDIP

HASIL DAN PEMBAHASAN

Produksi Amonia

Hasil penelitian menunjukkan bahwa produksi amonia akibat perlakuan pada berbagai zona di dalam kandang closed house dijelaskan pada Tabel 2:

Tabel 2. Produksi amonia berdasarkan masing-masing zona

\begin{tabular}{lcccc}
\hline \multirow{2}{*}{ Parameter } & \multicolumn{5}{c}{ Perlakuan } \\
\cline { 2 - 5 } & $\mathrm{T} 1$ & $\mathrm{~T} 2$ & $\mathrm{~T} 3$ & $\mathrm{~T} 4$ \\
\hline Amonia $(\mathrm{ppm})$ & $1,57^{\mathrm{d}}$ & $3,17^{\mathrm{c}}$ & $5,13^{\mathrm{b}}$ & $6,22^{\mathrm{a}}$ \\
\hline \multicolumn{2}{l}{ Keterangan :Superskrip berbeda pada baris yang sama menunjukkan perbedaan yang nyata $(\mathrm{p}<0,05)$}
\end{tabular}

Tabel 2. menunjukkan bahwa produksi amonia menunjukkan perbedaan nyata $(\mathrm{p}<0,05)$ semakin menjauhi inlet - dekat dengan outlet semakin meningkat. Hal ini diduga akibat suhu yang semakin meningkat, pada zona T4 (paling jauh dari inlet, paling dekat dengan outlet). Broiler yang dipelihara pada suhu lingkungan yang tinggi, mengakibatkan konsumsi air minum yang meningkat, mengakibatkan ekskreta cair, litter semakin basah. Litter yang basah menyebabkan fermentasi lebih tinggi, sehingga amonia semakin tinggi. Hal ini didukung oleh Kusnadi (2006) yang menyatakan bahwa konsumsi air minum yang meningkat pada broiler akibat suhu lingkungan broiler yang meningkat. Hal ini juga diperkuat oleh pendapat Metasari, Septinova, dan Wanniatie (2012) yang menyatakan litter yang basah, lebih cepat memacu proses fermentasi dan meningkatkan produksi $\mathrm{NH}_{3}$. Maliselo dan Nkonde (2015) juga berpendapat kelembaban litter yang terlalu tinggi mengakibatkan meningkatnya produksi amonia.

Hasil penelitian yang dilaksanakan pada musim penghujan ternyata tidak menjamin suhu yang selalu lebih rendah dibandingkan dengan musim kemarau. Hal ini sesuai data BMKG yang menunjukkan suhu Semarang pada musimpenghujan tidak terlalu rendah. Curah hujan yang tinggi, tidak selalu diikuti dengan suhu yang nyaman untuk broiler hidup, menyebabkan penulis menduga jika suhu tetap ideal untuk fermentasi amonia, maka kadar amonia dalam kandang tetap tinggi, ditambah kelembaban udara yang dihasilkan kan- 
dang tinggi baik dari luar kandang maupun dalam kandang yang berasal dari cooling pad.

\section{Kualitas Daging Ayam Broiler}

Hasil penelitian menunjukkan bahwa pengaruh kadar amonia pada kualitas daging akibat pemberian perlakuan pada berbagai zona di dalam kandang closed house dijelaskan pada Tabel 3:

Tabel 3. Kualitas Daging Broiler Akibat Perlakuan Zonasi

\begin{tabular}{|c|c|c|c|c|c|c|c|c|}
\hline \multirow{2}{*}{\multicolumn{3}{|c|}{ Parameter }} & \multicolumn{4}{|c|}{ Perlakuan } & \multirow{2}{*}{$\mathrm{P}$} & \multirow{2}{*}{ SE } \\
\hline & & & $\mathrm{T} 1$ & $\mathrm{~T} 2$ & T3 & $\mathrm{T} 4$ & & \\
\hline \multirow[t]{3}{*}{ WHC } & Paha Atas & & $20,930^{\mathrm{ab}}$ & $14,275^{\mathrm{c}}$ & $18,427^{\mathrm{bc}}$ & $24,527^{\mathrm{a}}$ & 0,00 & 0,19 \\
\hline & Paha Bawah & & 19,752 & 18,313 & 19,457 & 20,327 & 0,92 & 0,28 \\
\hline & Dada & & 17,013 & 12,316 & 18,023 & 16,74 & 0,06 & 0,18 \\
\hline \multirow[t]{3}{*}{$\mathrm{pH}$} & Paha Atas & & 6,660 & 6,617 & 6,650 & 6,683 & 0,83 & 0,05 \\
\hline & Paha Bawah & & 6,583 & 6,600 & 6,853 & 6,700 & 0,76 & 0,08 \\
\hline & Dada & & 6,617 & 6,200 & 6,217 & 6,317 & 0,52 & 0,07 \\
\hline \multirow[t]{9}{*}{ Warna } & Paha Atas & Red & $154,50^{\mathrm{ab}}$ & $166,83^{\mathrm{a}}$ & $144,667^{c}$ & $129,50^{\mathrm{c}}$ & 0,00 & 6,46 \\
\hline & & Green & $111,33^{\mathrm{ab}}$ & $123,66^{\mathrm{a}}$ & $100,167^{\mathrm{a}}$ & $86,000^{c}$ & 0,00 & 0,31 \\
\hline & & Blue & $100,00^{\mathrm{ab}}$ & $105,80^{\mathrm{a}}$ & $86,500^{\mathrm{bc}}$ & $75,167^{c}$ & 0,00 & 0,30 \\
\hline & Paha Bawah & Red & 153,600 & 135,000 & 127,830 & 130,330 & 0,29 & 0,43 \\
\hline & & Green & 103,750 & 87,670 & 67,330 & 87,830 & 0,15 & 0,63 \\
\hline & & Blue & $108,80^{\mathrm{a}}$ & $73,670^{\mathrm{ab}}$ & $49,170^{b}$ & $75,330^{\mathrm{ab}}$ & 0,01 & 0,06 \\
\hline & Dada & Red & 141,330 & 151,000 & 137,330 & 139,000 & 0,63 & 0,34 \\
\hline & & Green & 99,670 & 113,330 & 98,500 & 85,000 & 0,24 & 0,47 \\
\hline & & Blue & 81,830 & 81,000 & 83,330 & 68,000 & 0,43 & 0,50 \\
\hline \multicolumn{9}{|l|}{ Kadar } \\
\hline Air & Dada & & 79,150 & 79,433 & 79,850 & 76,017 & 0,13 & 2,21 \\
\hline \multicolumn{9}{|l|}{ Kadar } \\
\hline \multicolumn{9}{|l|}{ Lemak } \\
\hline Kasar & Dada & & 1,308 & 1,560 & 1,390 & 1,453 & 0,70 & 0,15 \\
\hline Kadar & & & & & & & & \\
\hline $\begin{array}{l}\text { Protein } \\
\text { Kasar }\end{array}$ & Dada & & $20,598^{b}$ & $20,860^{\mathrm{b}}$ & $21,115^{b}$ & $21,847^{\mathrm{a}}$ & 0,00 & 0,19 \\
\hline
\end{tabular}

Keterangan : Superskrip berbeda pada baris yang sama menunjukkan perbedaan yang nyata $(p<0,05)$

Berdasarkan hasil penelitian menunjukkan nilai WHC pada paha atas menujukkan peningkatan secara nyata $(\mathrm{p}<0,05)$ pada zonasi dekat outlet. Tabel diatas menunjukkan kisaran nilai WHC berada pada penelitian Hartono, Iriyanti, dan Santosa (2013) dengan WHC berkisar antara $16,97 \%$ - $21,74 \%$. Nilai WHC paha atas pada T1, T2, T3 tidak berbeda nyata, sedangkan pada T4 lebih tinggi secara nyata dibandingkan dengan T1, T2, T3.
Nilai WHC yang tinggi cenderung diikuti dengan warna daging yang gelap, karena kandungan air dalam daging kurang, menyebabkan kemampuan untuk menyerap warna meningkat dan membuat warna semakin gelap. Hal ini diduga karena broiler pada zona dekat outlet mendapatkan paparan amonia yang lebih banyak dan heat stress index yang signifikan lebih tinggi dibandingkan dengan zona yang dekat inlet (data belum publikasi), sehingga me- 
nyebabkan stres panas yang mengakibatkan stres oksidatif. Hal ini sesuai dengan pendapat Lin, Decuypere, dan Buyse (2006) yang menyatakan stres panas dapat dapat mengubah metabolisme tubuh broiler dan mengakibatkan stres oksidatif. Hal lain juga dikarenakan closed house mengakibatkan broiler mengalami stres jangka panjang atau kronik stres sebelum dipotong, sehingga daging cenderung DFD (Dry, Firm, Dark). Hal ini sesuai dengan pendapat Fletcher (2002); Adzitey dan Nurul (2011) yang menyatakan stres jangka panjang atau kronik stres dapat menyebabkan daging memiliki kondisi DFD. Hal ini juga diikuti dengan warna daging pada penelitian ini pada paha atas berbeda secara nyata pada T4 warna paling gelap. Hal ini sesuai dengan pendapat Suradi (2006) yang menyatakan bahwa warna daging yang memiliki WHC tinggi cenderung gelap.

Hasil penelitian menunjukkan, nilai $\mathrm{pH}$ pada bagian dada, paha atas, dan paha bawah tidak menunjukkan perbedaan yang nyata akibat zonasi. Nilai $\mathrm{pH}$ lebih tinggi dibandingkan standar normal $\mathrm{pH}$ daging broiler. Namun nilai $\mathrm{pH}$ pada tabel diatas masih berada pada beberapa penelitian dengan $\mathrm{pH} \geq 6,0$ (Adzitey dan Nurul, 2011; Kralik dkk, 2012; Fletcher, 2002). Lebih lanjut dijelaskan bahwa $\mathrm{pH}$ ultimate atau $\mathrm{pH}$ akhir $\geq 6,0$ memiliki kecendrungan DFD dan warna daging penelitian cenderung gelap pada paha atas, paha bawah, dan dada. Hal ini sesuai dengan pendapat Adzitey dan Nurul (2011); Kralik dkk. (2012); Fletcher (2002) yang menyatakan $\mathrm{pH}$ ultimate $\geq 6,0$ cenderung mengahasilkan daging dengan warna gelap.

Nilai pH yang tidak menunjukkan perbedaan nyata, diikuti dengan nilai WHC yang tidak berbeda nyata pada paha bawah dan dada. Pada penelitian ini kenaikan nilai WHC yang signifikan pada paha atas tidak diikuti dengan kenaikan $\mathrm{pH}$ yang signifikan, namun nilai pHcenderung memiliki pola kenaikan pada paha atas. Hal ini menunjukkan zonasi yang dekat outlet dan jauh dari inlet menyebabkan $\mathrm{pH}$ daging yang cenderung tinggi karena stres jangka panjang, sehingga menghasilkan warna daging cenderung gelap. Hal ini sesuai dengan pendapat Suradi (2006) yang menyatakan bahwa $\mathrm{pH}$ dan WHC memiliki pola yang sama.

Warna daging dalam penelitian ditunjukkan dengan nilai R (red), G (green), dan B (blue). Daging dada tidak menunjukkan perbedaan warna yang nyata, sedangkan pada bagian paha atas dan paha bawah (Blue) menunjukkan perbedaan warna yang nyata $(\mathrm{p}<0,05)$. Hasil penelitian warna daging pada paha atas menunjukkan perbedaan warna yang nyata, penempatan dekat outlet menghasilkan warna daging semakin gelap. Hal ini diduga karena nilai WHC paha atas menunjukkan zona dekat outlet secara nyata lebih gelap dibanding zona jauh dari outlet. WHC yang tinggi, menyebabkan kemampuan serat daging untuk memantulkan cahaya akan turun dan kemampuan menyerap warna meningkat, sehingga warna menjadi lebih gelap. Hal ini sesuai dengan pendapat Fletcher (2002) yang menyatakan bahwa WHC tinggi menyebabkan daging berwarna lebih gelap. Hal lain didugakarena kadar amonia dan heat stress index pada zona dekat outlet yang tinggi dalam kandang, membuat oksigen dalam udara berkurang, yang mengakibatkan stres oksidatif terjadi, sehingga oksigen dalam tubuh berkurang dan katabolisme glikogen meningkat menyebabkan asam laktat menumpuk diotot daging, dan daging menjadi gelap. Hal ini sesuai pendapat Zhang dkk. (2011) menyatakan aktivitas glikolisis dalam daging meningkatkan produksi asam laktat sehingga membuat warna daging gelap. Pengaruh zonasi dekat outlet menyebabkan warna daging cenderung gelap pada bagian paha atas dan paha bawah, karena stres jangka panjang menghasilkan daging yang DFD. Hal ini sesuai dengan pendapat Fletcher (2002); Adzitey dan Nurul (2011) 
yang menyatakan daging DFD dikarenakan stres panjang atau kronik stres pada broiler.

Berdasarkan hasil penelitian nilai kadar air dan lemak kasar daging dada tidak menunjukkan perbedaan yang nyata akibat zonasi. Kisaran kadar air pada tabel diatas tidak berbeda jauh dari penelitian Estancia dkk. (2012) dengan kadar air 75\%. Kisaran lemak kadar pada tabel berada pada kisaran penelitian Estancia dkk. (2012); Daud (2006) dengan kisaran 1,8\% - 2,12\%. Hasil penelitian menunjukkan kadar air daging dada tidak berbeda nyata, diikuti dengan nilai kadar lemak daging dada yang tidak berbeda nyata. Kadar air dan lemak memiliki nilai yang berbanding terbalik. Terlihat pada penelitian ini nilai kadar air pada T1 cenderung lebih tinggi, diikuti dengan kadar lemak T1 yang lebih rendah (Tabel 3). Hal ini sesuai dengan pendapat Soeparno (1994); Becker dkk. (1981) yang menyatakan nilai kadar air dan kadar lemak memiliki korelasi negatif. Hal ini menunjukkan zonasi dekat inlet atau dekat outlet belum mempengaruhi kadar air dan kadar lemak kasar daging dada. Penelitian ini juga tidak menunjukkan perbedaan nyata pada lemak abdominal (data belum publikasi), penulis menduga pemafaatan kelebihan energi tidak sampai tahapan deposisi lemak, sehingga tidak terjadi penimbunan lemak baik pada lemak kasar maunpun lemak abdominal.

Kadar protein kasar bagian dada, menunjukkan adanya perbedaan nyata yang semakin tinggi akibat penempatan pada zona dekat outlet $(\mathrm{p}<0,05)$. Hasil evaluasi kadar protein kasar daging pada penelitian ini masih berada pada kisaran normal. Hal ini sesuai hasil penelitian Estancia dkk. (2012); Campbell dan Lasley (1975) dengan kisaran protein kasar daging dada $19,3 \%-20,6 \%$. Meskipun demikian penulis menduga peningkatan kadar protein kasar pada penempatan zona dekat outlet hanya disebabkan variasi individu, karena setelah dianalisis lebih lanjut untuk massa protein daging yang mempresentasikan total deposisi protein pada broiler, masih lebih baik pada penempatan zona T1. Hal ini menunjukkan bobot tubuh pada zona $\mathrm{T} 1$ lebih besar dibandingkan dengan T4, sehingga menghasilkan massa protein yang lebih besar. Hal ini sesuai dengan pendapat Maharani, Suthama, dan Wahyuni (2013) bobot daging yang lebih besar mendoposisikan massa protein daging yang lebih besar.

\section{KESIMPULAN}

Penempatan zona yang dekat dengan outlet mempengaruhi kualitas daging dari segi WHC yang baik, namun warna daging lebih gelap, dan protein kasar yang baik, meskipun tidak diikuti massa proteinnya. Hal ini menunjukkan zonasi dalam kandang closed house terhadap produksi amonia di musim penghujan berpotensi memberikan pengaruh kurang baik pada kualitas daging ayam broiler dari segi warna.

\section{DAFTAR PUSTAKA}

Adzitey, F. dan Nurul, H. 2011. Pale soft exudative (PSE) and Dark firm dry (DFD) meats: causes and measures to reduce these incidences - a mini review. International Food Research Journal, 18 (2011): 11 - 20.

AOAC. 1984. Official Method of Analysis of AOAC. 14th Edition. AOAC Inc., Arlington, Virginia.

Apriyantono, A., D. Fardiaz, N.H. Puspitasari, Sudarnawati, dan S. Budiyanto. 1987. Analisis Pangan. Institut Pertanian Bogor Press, Bogor.

Assad. H.A., E. Widiastuti., dan S. Sugiharto. 2016. Penaruh penambahan onggok terfermentasi dan/atau antibiotik dalam ransum terhadap kualitas liter dan footpad ayam broiler. Prosiding Seminar Nasional Peternakan Berkelanjutan. Sumedang, 16 November 2016. 
Barbut, S. 1993. Colour measurements for evaluating the pale soft exudative (PSE) occurrence in turkey meat. Journal Food Research International, 1 (26): 39 - 43.

Becker, W.A., J.V. Spencer, L.W. Mirosh, dan J.A.Verstrate. 1981. Abdominal and carcass fat in five broiler strain. Poultry Science Journal, 4 (60): 693 $-697$.

Campbell, J. R., and Lesley, J. F.. 1975. The Science of Animal That Serve Mankind. Tata McGraw-Hill Publishing Company Limited. New Delhi.

Charles, D. R. 2002. Responses to the thermal environment. In Poultry Environment Problem, A guide to solution. Nottingham University Press, Nottingham, United Kingdom.

Daud, M. 2006. Persentase dan Kualitas Karkas Ayam Pedaging yang Diberi Probiotik dan Prebiotik dalam Ransum. Jurnal Ilmu Ternak, 6(2): 126 $-131$.

Estancia, K., Isroli, Nurwantoro. 2012. Pengaruh pemberian ekstrak kunyit (Curcuma demostica) terhadap kadar air, protein, dan lemak daging ayam broiler. Animal Agriculture Journal, 1(2): 31 - 39.

Fletcher, D.L. 2002. Poultry meat quality. World Poultry Science Journal, 2 (58) : $131-145$.

Hartono, E., N. Iriyanti, dan R.S.S. Santosa. 2013. Penggunaan pakan fungsional terhadap daya ikat air, susut masak, dan keempukan daging ayam broil- er. Jurnal Ilmiah Peternakan,1(1): $10-19$.

Hayse, P.L. dan W.W. Marion. 1973. Eviscerated yield, component parts, and meat skin and bone rations in the chicken broiler. Poultry Science Journal, 2(52) : 718 - 722 .

Kralik, G., I. Djurkin, Z. Kralik, Z. Skrtic, dan Z. Radisic. 2014. Quality indicators of broiler breast meat in relation to colour. Animals Science Papers and Reports, Institute of Genetics and Animal Breeding, Jastrzębiec, Poland, 2(32): 173 -178.

Kusnadi, E. 2006. Suplementasi vitamin c sebagai penangkal cekaman panas pada ayam broiler. JITV, 4(11): 249 $-253$.

Lin, H., E. Decuypere, dan J. Buyse. 2006. Acute heat stress incudes oxidative stress in broiler chickens. Journal Comparative Biochemistry and Physiology, 144(2006): $11-17$.

Maharani, P., N. Suthama, dan H.I. Wahyuni. 2013. Massa kalsium dan protein daging pada ayam arab petelur yang diberi ransum menggunakan Azolla microphylla. Animal Agriculture Journal, 1(2): $18-27$.

Maliselo, P.S., dan G.K. Nkonde. 2015. Amonia production in poultry houses and its effect on the growth of gallus gallus domestica (broiler chickens): a case study of a small scale poultry house in Riverside, Kitwem Zambia. International Journal of Scientific and Technology Research, 4(4): 141 -145 .

Metasari, T. D. Septinova, dan V. Wanniatie. 2012. Pengaruh berbagai jenis bahan litter terhadap kualitas 
litter broiler fase finisher di closed house. Jurnal Ilmiah Peternakan Terpadu, 3(2): $23-29$.

Miles, D.M., S. L. Branton, dan B.D. Lott. 2004. Atmospheric ammonia is detrimental to the performance of modern commercial broilers. Journal Poultry Science, 10(83): 1650 - 1654.

Pereira, J.L.S. 2017. Assessment of ammonia and greenhouse gas emissions from broiler houses in Portugal. Atmospheric Pollutiongogo Research, 8(2017): 949 - 955.

Pratikno, H. 2010. Pengaruh ekstrak kunyit (Curcuma Domestica Vahl) terhadap bobot badan ayam broiler (Gallus Sp). Buletin Anatomi dan Fisologi, 18(2): 39-46.

Sarjana, T.A., L.D. Mahfudz, M. Ramadhan, Sugiharto, F. Wahyono, dan S. Sumarsih. 2017. Emisi ammonia dan kondisi litter pada kandang ayam broiler sistem terbuka yang mendapatkan additive berbeda dan kombinasinya dalam ransum. Seminar Nasional Pengembangan Peternakan Berkelanjutan, Universitas Padjajaran. Sumedang.

Soeparno. 2005. Ilmu dan Teknologi Daging. Gadjah Mada University Press, Yogyakarta.

Soeparno. 1994. Ilmu dan Teknologi Daging. Gadjah Mada University Press, Yogyakarta.

Sujana, E., S. Darana, dan L. Setiawan. 2011. Implementasi teknologi semi closed - house system pada performan ayam broiler di test farm sustainable livestock techno park, kampus Fakultas Peternakan Universitas Padjadjaran, Jatinangor.
Seminar Nasional Teknologi Peternakan dan Veteriner : 362 - 366.

Suradi, K. 2006. Perubahan Sifat Fisik Daging Ayam Broiler Post Mortem Selama Penyimpanan Temperatur Ruang. Jurnal Ilmu Ternak, 6(1): 23 -27 .

Sudarmadji, S. Haryono, dan Suhardi. 1989. Prosedur Analisis untuk Bahan Makanan dan Pertanian. Liberty, Yogyakarta.

William, D.W. dan R. Meijerhof. 1990. The Effect of Different Levels of Relative Humidity and Air Movement on Litter Conditions, Ammonia Levels, Growth, and Carcass Quality for Broiler Chickens. Journal Poultry Science, 70 : 746- 755.

Xing, H., S. Luna., Y. Sun., R. Sa., dan H. Zhang. 2016.Effects of ammonia exposure on carcass traits and fatty acid composition of broiler meat. Journal Animal Nutrion, 2(2016): $282-287$.

Zhang, Y.Z., G.Q.Jia, J. J. Zuo, Y. Zhang, J. Lei, L. Ren, dan D.Y. Feng. 2012.Effects of constant and cyclic heat stress on muscle metabolism and meat quality of broiler breast fillet and thigh meat. Poultry Science Oxford Academic, 11(91): $2931-2937$. 